\title{
Measurement of radon gas concentration in water and soil samples in AL-Najaf governorate by using nuclear track detector (CR-39)
}

\author{
Taghreed K. Hameed \\ Department of Physics, College of Education, University of Al-Mustansiriyah \\ Received 2, April, 2014 \\ Accepted 28, September, 2014 \\ (i) $\Theta \Theta$ \\ c.
} NoDerivatives 4.0 International Licens

\section{Abstract:}

The radon gas concentration in environmental samples soil and water of selected regions in Al-Najaf governorate was measured by using alpha-emitters registrations which are emitted form radon gas in (CR-39) nuclear track detector. The first part is concerned with the determination of radon gas concentration in soil samples, results of measurements indicate that the highest average radon concentration in soil samples was found in (Al-Moalmen) region which was $\left(100.0 \pm 7.0 \mathrm{~Bq} / \mathrm{m}^{3}\right)$, while the lowest average radon concentration was found in (Al-Askary) region which was $(38.5 \pm 4.7$ $\left.\mathrm{Bq} / \mathrm{m}^{3}\right)$, with an average value of $\left(64.23 \pm 14.9 \mathrm{~Bq} / \mathrm{m}^{3}\right)$, the results show that the radon gas concentrations in soil is below the allowed limit from (ICRP) agency which is $\left(200 \mathrm{~Bq} / \mathrm{m}^{3}\right)$, while the radon exhalation rate (RER) ranged from (35.23-91.52 $\left.\mu \mathrm{Bq} / \mathrm{m}^{2} \mathrm{~h}\right)$, and average value which was $\left(58.77 \pm 13.6 \mu \mathrm{Bq} / \mathrm{m}^{2} \mathrm{~h}\right)$.

The second part is concerned with the determination of radon gas concentration in samples of tap water obtained from networks in dwellings in Al-Najaf governorate, the results indicate that the highest average radon concentration in water samples was found in (Meassan) region which was $(0.59 \pm 0.08 \mathrm{~Bq} / \mathrm{L})$, while the lowest average radon concentration was found in (Al-Jamhorah) region which was $(0.16 \pm 0.04 \mathrm{~Bq} / \mathrm{L})$, with an average value of $(0.36 \pm 0.1 \mathrm{~Bq} / \mathrm{L})$, the present results show that the radon gas concentrations in tap water is below the allowed limit from (ICRP) agency which is $(0.5994 \mathrm{~Bq} / \mathrm{L})$, while the radon exhalation rate (RER) ranged from $(2.15-0.58 \mu \mathrm{Sv} / \mathrm{y})$, and average value which was $(1.28 \pm 0.31 \mu \mathrm{Sv} / \mathrm{y})$.

Key words: Radon concentration, Soil, Radon exhalation rate, CR-39 nuclear track detector.

\section{Introduction:}

Gaseous radioactive radon $\left({ }^{222} \mathrm{Rn}\right)$, decay product of the radium isotope ${ }^{226} \mathrm{Ra}$ presents in all types of soil and rock. Radium atoms decays in soil particles, the resulting atoms of radon entering to air filled pores and then transported by diffusion and advection through this space in order to exhale into the atmosphere [1]. Radon concentrations in soil gas within few meters of the surface of the ground are clearly important in determining radon rates of entry into pore spaces and subsequently into the atmosphere and it's depend on the radium concentration in the bedrock and on the permeability of the soil [2]. Since radon is a gas, it may escape into the air from the material in which it is formed, and since uranium and radium 
occur widely in soil and water, radon gas is ubiquitous-outdoors as well as indoors, the air that we inhale contains radon [3] .

Some radon stays in the tap water containing radon presents a risk of developing internal organ cancers, primarily stomach cancer [4]. However, this risk is smaller than the risk of developing lung cancer from radon released to air from water. When water leaves a faucet, dissolved gases are released. [5].

The aim of the present work is to determine the radon gas concentration in soil surface and tap water samples in selected regions in AL-Najaf governorate by using alpha-emitters registrations which are emitted form radon gas in (CR-39) nuclear track detector by using the sealed-cup technique.

\section{Materials and Methods:}

\section{.A- Description of Study Area}

AL-Najaf governorate is located in the south of Iraq and in the southwest of Baghdad governorate (the capital of the republic of Iraq), and it is about $161 \mathrm{~km}$ far from Baghdad governorate, with location of latitude $32^{\circ} \mathrm{N}$, and longitude $44^{\circ} \mathrm{E}$. It is located about 70 $\mathrm{m}$ above the sea level, with a total area of nearly $28,824 \mathrm{~km}^{2}$ and a population of nearly 1,200,000 inhabitants. ALNajaf governorate has a desert climate characterized by extreme heat during the day, an abrupt drop in temperature at night, and slight, erratic rainfall. The weather in AL-Najaf governorate is dry and hot in summer; cold and less rainy in winter. Najaf governorate does not have a seaport. Its lands are flat and leveled in areas linked to waters from the Euphrates River and higher in the southern portions of the desert areas, extending to the republic of Iraq [6], in the present work radon concentrations, were measured for soil and tap water samples in different locations for 10 different regions in AlNajaf governorate which includes regions (Al-Forat, Al-Askary, Tamoz , Al-Motanaby , Meassan, Al-Askan, Al-Moalmen , Al-Karama, Al-Zahraa , Al-Jamhorah), the first part was measured for soil sample, from table (1) summarize the results obtained in the present work for radon gas concentrations in soil samples in different sites in Al-Najaf governorate .

\section{B- Calculation of Radon gas concentration}

The determination of the concentrations of alpha particles emitted from radon gas in soil and water samples were performed by using the nuclear track detector (CR-39) of thickness of about $(250 \mu \mathrm{m})$ and area of about $\left(1 \times 1 \mathrm{~cm}^{2}\right)$.

The samples surface of soils were collected from different sites in AlNajaf governorate, the surface soil samples were crushed to small pieces then to fine powder by using electrical mill, the fine soil powder will convert to the grain size of $(200 \mu \mathrm{m})$. The weight of the sample was of about (40 g). The samples of tap water were also collected from the same sites of the above Al-Najaf governorate, $(0.25$ litter) volume of tap water, the tap water obtained from the water networks in dwellings in Al-Najaf governorate, the radon gas concentration in soil and water samples was obtained by using the sealed-cup technique as shown in Fig. (1) and Fig. (2), respectively.

After the irradiation time (30 day), the (CR-39) track detectors were etched in $(6.25 \mathrm{~N}) \quad(\mathrm{NaOH})$ solution at temperature of $\left(60{ }^{\circ} \mathrm{C}\right)$ for $(7 \mathrm{~h})$, and the tracks density were recorded using an optical microscope with magnification (400x).Calculation of Radon gas concentration:

The radon gas concentration in the soil and water samples were obtained by 
the comparison between track densities registered on the detectors of the sample and that of the standard soil and water samples which are shown in Fig.(3) and Fig. (4) respectively, using the relation [7]:

The density of the tracks $(\rho)$ in the samples were calculated according to the following relation [8].

Tracks density

$(\rho)=\frac{\text { Average number of total pits (track) }}{\text { Area of field view }}$

... (1)

$\mathrm{C}_{\mathbf{X}}=\rho_{\mathbf{X}} \cdot\left(\mathrm{C}_{\mathbf{S}} / \rho_{\mathbf{S}}\right)$

Where :

$\mathrm{C}_{\mathbf{X}}$ : alpha particles concentration in the unknown sample.

$\mathrm{C}_{\mathbf{S}}$ : alpha particles concentration in the standard sample.

$\rho_{\mathbf{X}}$ : track density of the unknown sample (track/mm²).

$\rho_{\mathbf{S}}:$ track density of the standard sample (track $/ \mathrm{mm}^{2}$ ).

C-Calculation of radon exhalation rate in soil samples

The radon exhalation rate of any sample is defined as the flux of radon released from the surface of material. The surface exhalation rate $\left(E_{e x h}\right)$ in units Bq. $\mathrm{m}^{-2} \cdot \mathrm{h}^{-1}$ can be calculated by [9]:

$$
E_{e x h}=\frac{C V \lambda}{A\left[T+\lambda^{-1}\left(e^{-\lambda T}-1\right)\right]}
$$

Where:

$\mathrm{C}$ : is the integrated radon exposure (Bq. $\mathrm{m}^{-3}$ ).

$\mathrm{V}$ : is the volume of air in cup $\left(\mathrm{m}^{3}\right)$ $=140 \mathrm{~cm}^{3}=0.00014 \mathrm{~m}^{3}$

$\lambda$ :is the decay constant for ${ }^{222} \mathrm{Rn}\left(\mathrm{h}^{-1}\right)$ $=0.1812$ day $^{-1}=0.00755 \mathrm{~h}^{-1}$

A: is the surface area of the sample $\left(\mathrm{m}^{2}\right) \quad=\quad 2.5^{2} \times 3.14=19.63$ $\mathrm{cm}^{2}=0.0019636 \mathrm{~m}^{2}$

$\mathrm{T}$ : is the exposure time $(\mathrm{h})=30$ day $=720 \mathrm{~h}$

\section{D- Calculation the annual effective dose in water samples}

The annual effective dose of an individual consumer due to intake of radon from tap water is evaluated using the relationship [10]

$\mathrm{AED}_{\mathrm{w}}=\mathrm{C}_{\mathrm{w}} \mathrm{C}_{\mathrm{Rw}} \mathrm{D}_{\mathrm{cw}}$

Where $\mathrm{AED}_{\mathrm{w}}$ is the annual effective dose $(\mathrm{Sv} / \mathrm{y})$ due to ingestion of radionuclide from the consumption of water.

$\mathrm{C}_{\mathrm{w}}$ is the concentration of radon in the ingested drinking water $(\mathrm{Bq} / \mathrm{L})$.

$\mathrm{C}_{\mathrm{Rw}}=730 \mathrm{~L} / \mathrm{y}, D_{c w}$ is $=5 \times 10^{-9}$ $\mathrm{Sv} / \mathrm{Bq}$

\section{Results and Discussion:}

From Table (1) it can be noticed that, the highest average radon concentration in soil samples was found in (AlMoalmen) region which was $\left(100.0 \pm 7.0 \mathrm{~Bq} / \mathrm{m}^{3}\right)$, while the lowest average radon concentration was found in (Al-Askary) region which was $\left(38.5 \pm 4.7 \mathrm{~Bq} / \mathrm{m}^{3}\right)$, see fig. (5), with an average value of $\left(64.23 \pm 14.9 \mathrm{~Bq} / \mathrm{m}^{3}\right)$, the present results show that the radon gas concentration in soil is below the allowed limit from (International Commission of Radiation Protection) (ICRP) agency which is $\left(200 \mathrm{~Bq} / \mathrm{m}^{3}\right)$ [11], while the radon exhalation rate (RER) ranged from (35.23-91.52 $\mu \mathrm{Bq} / \mathrm{m}^{2} \mathrm{~h}$ ), and average value which was $\left(58.77 \pm 13.6 \mu \mathrm{Bq} / \mathrm{m}^{2} \mathrm{~h}\right)$.

The second part is concerned with determination of radon gas concentration in samples of tap water obtained from networks in dwellings in Al-Najaf governorate, from Table (2), it can be noticed that, the highest average radon concentration in water samples was found in (Meassan) region which was $(0.59 \pm 0.08 \mathrm{~Bq} / \mathrm{L})$, while the lowest average radon concentration was found in (AlJamhorah) region which was $(0.16 \pm 0.04 \mathrm{~Bq} / \mathrm{L})$, see Fig. (6), with an average value of $(0.36 \pm 0.1 \mathrm{~Bq} / \mathrm{L})$, the present results show that the radon gas concentration in tap water is below the allowed limit from (International Commission of Radiation Protection) (ICRP) agency which is $(0.5994 \mathrm{~Bq} / \mathrm{L})$ 
[12], while the radon exhalation rate (RER) ranged from (2.15-0.58 $\mu \mathrm{Sv} / \mathrm{y})$, and average value which was $(1.28 \pm 0.31 \mu \mathrm{Sv} / \mathrm{y})$.

It might be mentioned that, thoron gas is an alpha emitter which is also present in soil and water environments, however, the average diffusion distance of thoron gas is very small compared to that of radon [10], which means that the present results might also contained a small amount of thoron, and therefore might be considered roughly as an upper limit results which are still within the allowed limit of (ICRP) agency . Also it should be remembered that the halflives of radon and thoron are about $(3.82 \mathrm{~d})$ and $(56 \mathrm{~s})$ respectively. However, the present result might be more refined be using, for example, a filter to separate radon gas from thoron gas [13].

\section{Conclusions}

From the present work, it can be concluded that, in soil samples the results show that the radon gas concentration in soil is below the allowed limit from (ICRP) agency which is $\left(200 \mathrm{~Bq} / \mathrm{m}^{3}\right)$, while in tap water samples the results show that the radon gas concentration in tap water is below the allowed limit from (ICRP) agency which is $(0.5994 \mathrm{~Bq} / \mathrm{L})$.

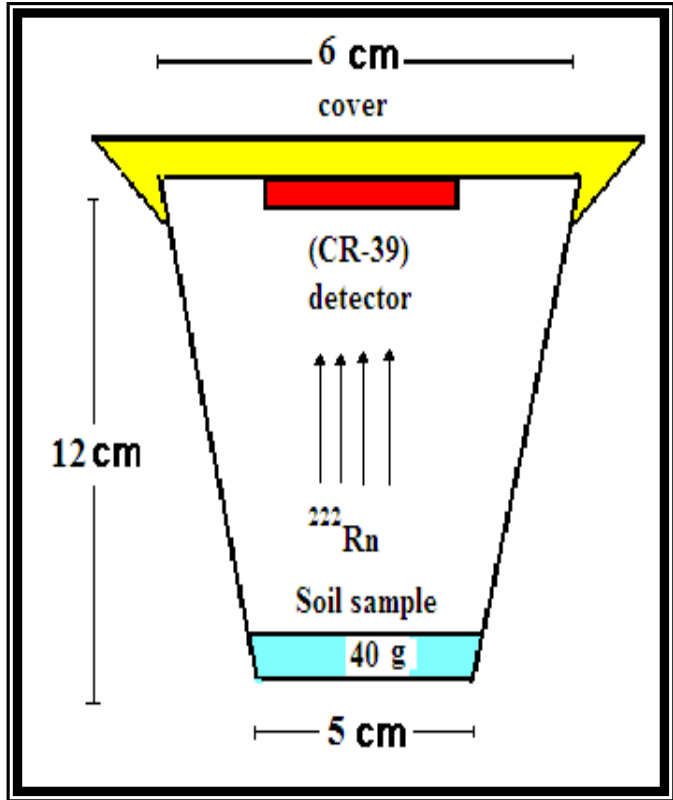

Fig.(1) A schematic diagram of the sealed-cup technique in soil sample.

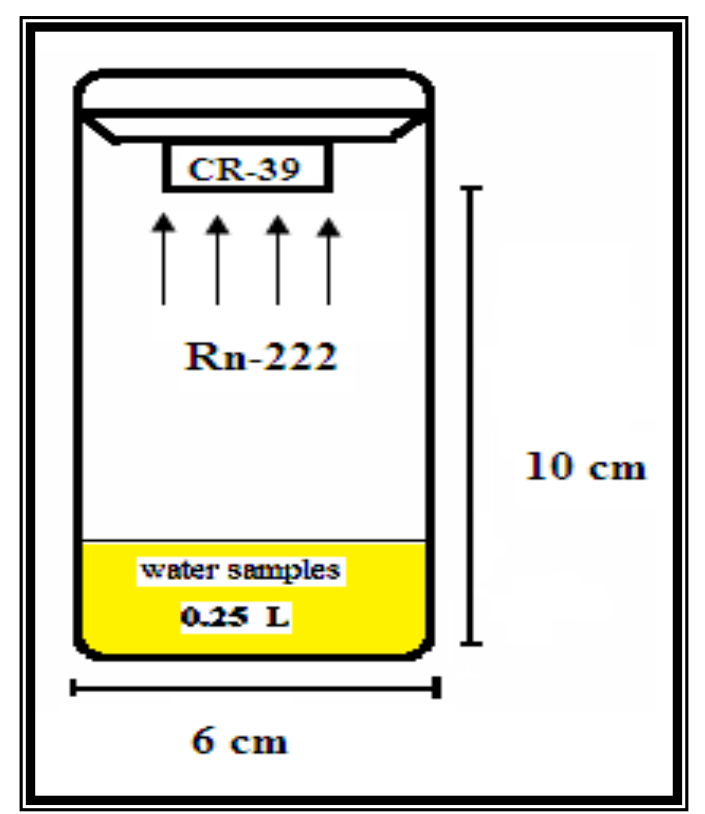

Fig.(2) A schematic diagram of the sealed-cup technique in water sample. 


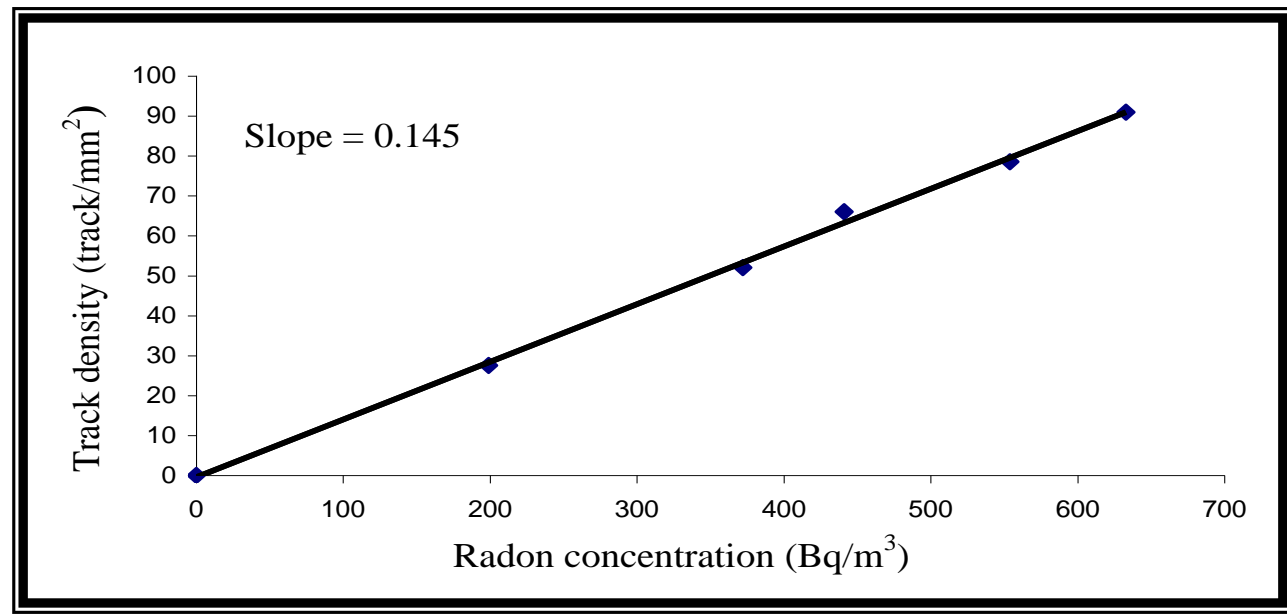

Fig.(3) relation of radon gas concentration and track density in soil standard samples.

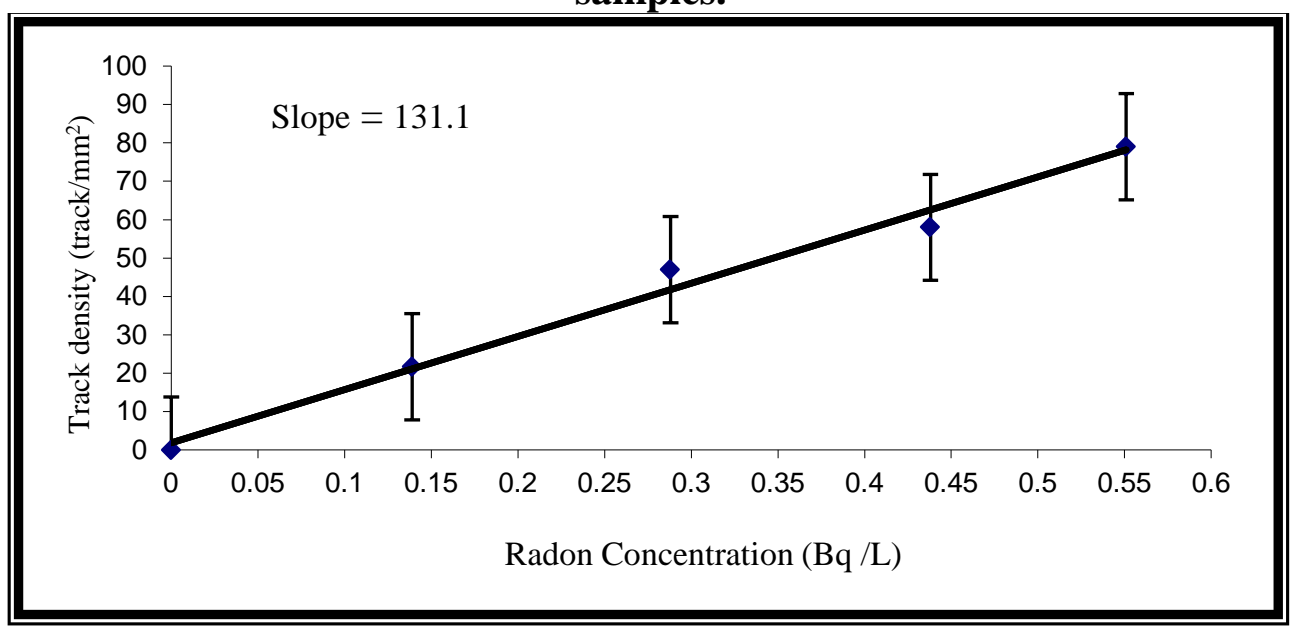

Fig.(4) relation of radon gas concentration and track density in water standard samples.

Table (1) shows the radon gas concentration $\mathrm{C}_{\mathrm{Rn}}\left(\mathrm{Bq} / \mathrm{m}^{3}\right)$, radon exhalation rate (RER), for soil samples in Al-Najaf governorate.

\begin{tabular}{|c|c|c|c|c|c|c|c|}
\hline \multirow{2}{*}{ No. } & \multirow{2}{*}{ Region } & \multicolumn{4}{|c|}{$C_{R n}\left(B q / m^{3}\right)$} & \multirow[t]{2}{*}{ Mean of $C_{R n}\left(B q / m^{3}\right)$} & \multirow{2}{*}{$\begin{array}{c}(\mathbf{R E R}) \\
\left(\mu \mathrm{Bq} / \mathbf{m}^{2} \mathbf{h}\right)\end{array}$} \\
\hline & & 1 & 2 & 3 & 4 & & \\
\hline 1 & Al-Forat & 44 & 48 & 54 & 58 & $51.0 \pm 4.0$ & 46.67 \\
\hline 2 & Al-Askary & 32 & 37 & 37 & 48 & $38.5 \pm 4.7$ & 35.23 \\
\hline 3 & Tamoz & 65 & 66 & 70 & 72 & $68.25 \pm 2.7$ & 62.46 \\
\hline 4 & Al-Motanaby & 48 & 54 & 57 & 61 & $55.0 \pm 4.0$ & 50.33 \\
\hline 5 & Meassan & 43 & 48 & 54 & 59 & $51.0 \pm 5.5$ & 46.67 \\
\hline 6 & Al-Askan & 59 & 64 & 71 & 82 & $69.0 \pm 7.7$ & 63.15 \\
\hline 7 & Al-Moalmen & 92 & 94 & 104 & 110 & $100.0 \pm 7.0$ & 91.52 \\
\hline 8 & Al-Karama & 78 & 84 & 88 & 96 & $86.5 \pm 5.5$ & 79.17 \\
\hline 9 & Al-Zahraa & 43 & 45 & 56 & 62 & $51.5 \pm 7.0$ & 46.67 \\
\hline 10 & Al-Jamhorah & 64 & 66 & 74 & 84 & $72.0 \pm 7.0$ & 65.89 \\
\hline & Average & & & & & $64.23 \pm 14.9$ & $58.77 \pm 13.6$ \\
\hline
\end{tabular}


Table (2) radon gas concentration $\mathrm{C}_{\mathrm{Rn}}\left(\mathrm{Bq} \cdot \mathrm{L}^{-1}\right)$, annual effective dose (AED), for tap water samples in Al-Najaf governorate.

\begin{tabular}{|c|c|c|c|c|c|c|c|}
\hline \multirow{2}{*}{ No. } & \multirow{2}{*}{ Region } & \multicolumn{7}{|c|}{$\mathbf{C}_{\mathbf{R n}}\left(\mathbf{B q . \mathbf { L } ^ { - 1 } )}\right.$} & \multirow{2}{*}{$\begin{array}{c}\text { Mean of } \mathbf{C}_{\mathbf{R n}} \\
\left(\mathbf{B q} . \mathbf{L}^{-1}\right)\end{array}$} & $\begin{array}{c}(\mathbf{A E D}) \\
(\boldsymbol{\mu} \mathbf{S v} / \mathbf{y})\end{array}$ \\
\hline 1 & Al-Forat & 0.16 & 0.20 & 0.33 & 0.43 & $0.28 \pm 0.1$ & 1.02 \\
\hline 2 & Al-Askary & 0.34 & 0.42 & 0.54 & 0.57 & $0.46 \pm 0.08$ & 1.80 \\
\hline 3 & Tamoz & 0.21 & 0.25 & 0.43 & 0.57 & $0.36 \pm 0.13$ & 1.31 \\
\hline 4 & Al-Motanaby & 0.43 & 0.43 & 0.49 & 0.53 & $0.47 \pm 0.04$ & 1.17 \\
\hline 5 & Meassan & 0.43 & 0.60 & 0.63 & 0.71 & $0.59 \pm 0.08$ & 2.15 \\
\hline 6 & Al-Askan & 0.33 & 0.34 & 0.41 & 0.54 & $0.40 \pm 0.07$ & 1.46 \\
\hline 7 & Al-Moalmen & 0.21 & 0.25 & 0.32 & 0.43 & $0.30 \pm 0.07$ & 1.09 \\
\hline 8 & Al-Karama & 0.24 & 0.30 & 0.36 & 0.47 & $0.34 \pm 0.07$ & 1.24 \\
\hline 9 & Al-Zahraa & 0.22 & 0.23 & 0.34 & 0.38 & $0.29 \pm 0.06$ & 1.05 \\
\hline 10 & Al-Jamhorah & 0.11 & 0.13 & 0.17 & 0.23 & $0.16 \pm 0.04$ & 0.58 \\
\hline
\end{tabular}

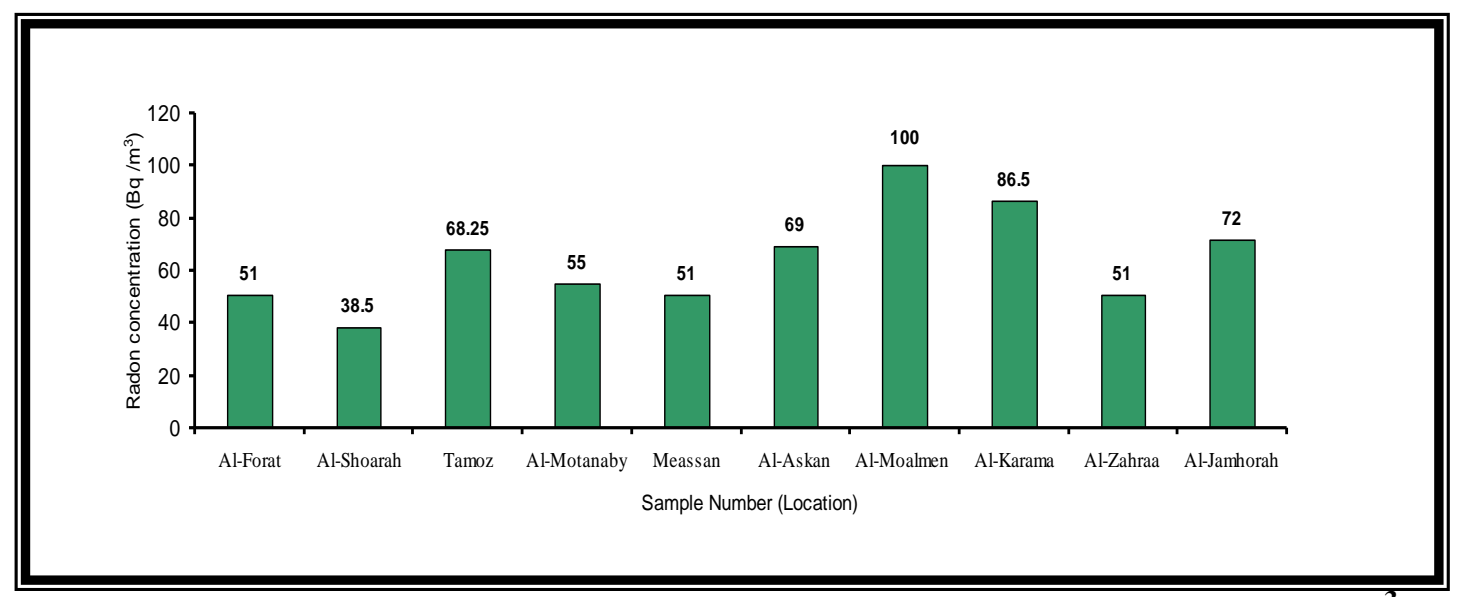

Fig.(5) A histogram illustrating the change in radon gas concentration $\left(\mathrm{Bq} / \mathrm{m}^{3}\right)$ in soil samples in all regions studied.

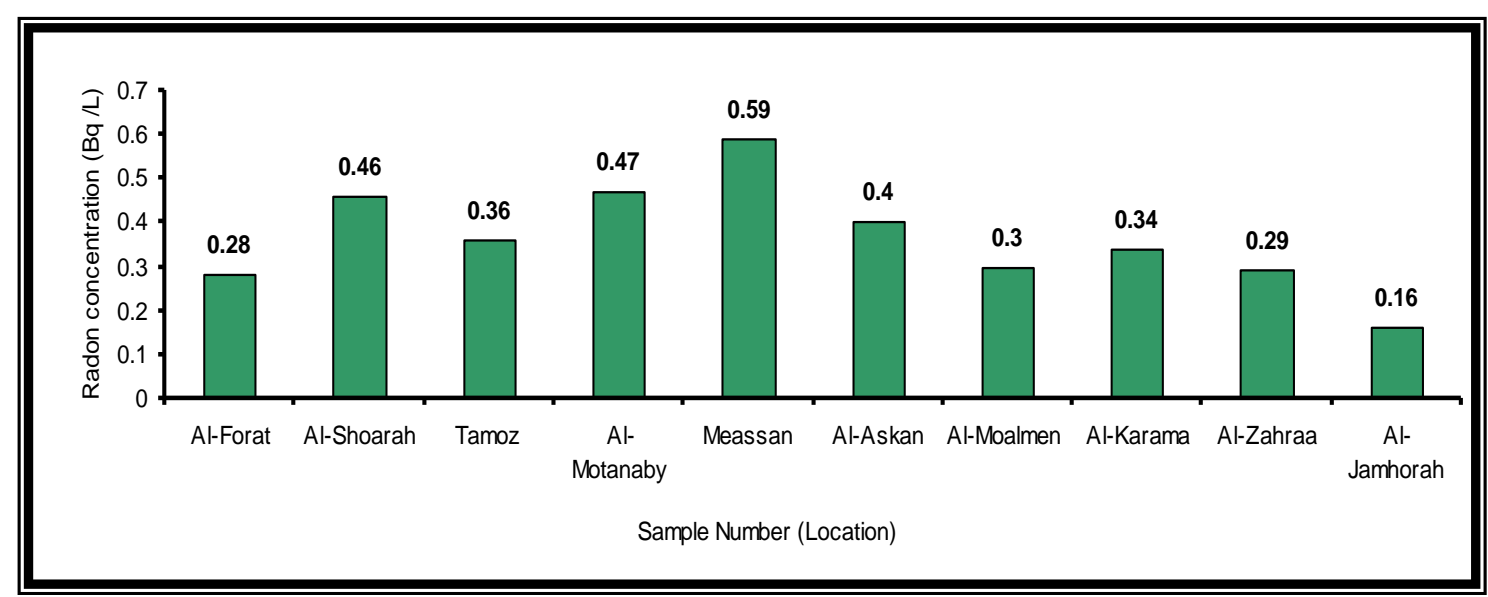

Fig.(6) A histogram illustrating the change in radon gas concentration $(\mathrm{Bq} / \mathrm{L})$ in water samples in all regions studied. 


\section{References:}

[1] UNSCEAR Annex A., 1988. Sources and effects of ionizing radiation. United Nations Scientific Committee on the Effect of Atomic Radiation, United Nations, New York .

[2] UNSCEAR Annex B., 2000. Sources and effects of ionizing radiation. United Nations Scientific Committee on the Effect of Atomic Radiation, United Nations, New York .

[3] Iskandar, D.; Iida, T.; Yamazawa, H.; Moriizumi, J.; Koarashi, J.; Yamasoto, K.; Yamasaki, K.; Shimo, Tsujimoto M. T.; Ishikawa, S.; Fukuda M. and Kojima H. , 2005. The transport mechanisms of ${ }^{222} \mathrm{Rn}$ in soil at Tateishi as an anomaly spot in Japan. Appl. Rad. and Isotopes, 63: 401-408.

[4] Radiation protection against radon in workplaces other than mines, (2003), International atomic energy agency, safety reports series, 33: 3-4, Vienna.

[5] Risk Assessment of Radon in Drinking Water, 1999. Committee on Risk Assessment of Exposure to Radon in Drinking Water, National Research Council, pp. 296.

[6] Kadhem M.M. 2013. Estimation of radon concentration and annual effective dose in Al-Najaf city hospitals. M.Sc. Thesis, Kufa University, College of Science.

[7] Amalds, O.; Custball, N. H. and Nielsen G.A., $1989 .{ }^{137} \mathrm{Cs}$ in
Montarq Soils . Hea. Phy., 57 (6): 955-958.

[8] Durrani, S. A. and Bull, R. K., 1987. Solid State Nuclear Track Detection: Principles, Methods and Applications. Pergammon Press, U.K..

[9] Mahur, A. K.; Kumar, R.; Mishra, M.; Ali, S. A.; Sonkawade, R. G.; Singh, B. P.; Bhardwaj, V. N.; Prasad, R.; Ind. J., 2010.Pure and Appl. Phys., 48 :486-491.

[10] Alam, M. N.; Chowdhry, M. I.; Kamal, M.; Ghose, S.; Islam, M. N. and Awaruddin M., 1999. Radiological assessment of drinking water of the Chittagong region of Bangladesh, Radiat. Prot. Dosim., 82:207-214.

[11] International Commission on Radiological Protection Against Radon-222 at Home and Work. 1993. Publication 65, Pergamon Elsevier, 35:242-247.

[12] Al-Ubaidi, K. H., 2006. Identification and measurements of natural and industrial radioactive pollutants in environment of Baghdad city using gamma spectrometry and solid state nuclear track detector CR-39. Ph.D. Thesis, College of Education, Ibn-Alhaitham ,University of Baghdad.

[13] Saad, B. M. 1998. Determination of radon concentrations in buildings by using nuclear track detector (CR-39). M.Sc. Thesis, College of Education, IbnAlhaitham ,University of Baghdad. 


\section{قياس تزكيز غاز الرادون في نماذج من التربة والمياه في محافظة النجف باستخدام كاشف الأثز النووي (CR-39)}

\section{تغريد خالا حميا}

قسم الفيزياء ، كلية التربية ، الجامعة المستتصرية

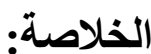

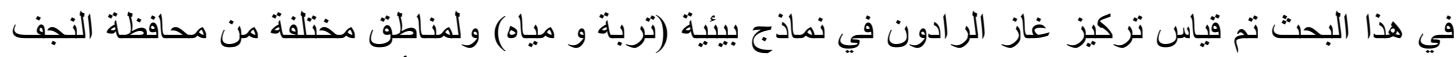

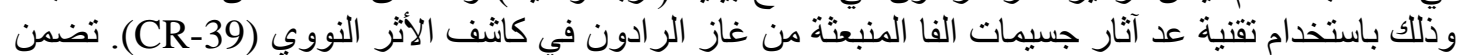

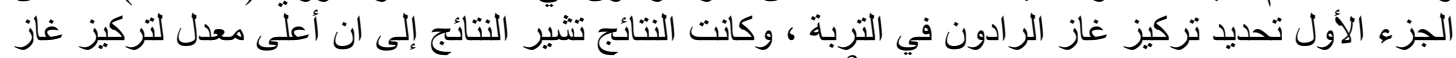

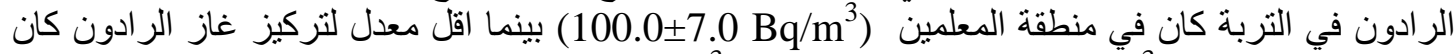

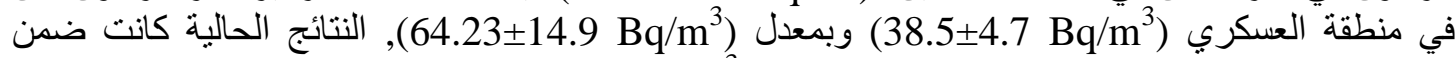

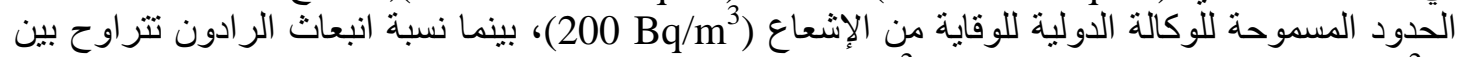

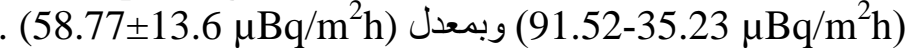

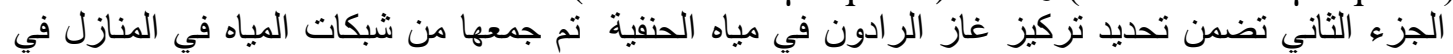

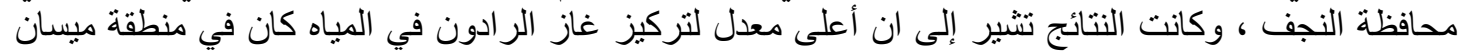
(0.59_0.08 Bq/L)

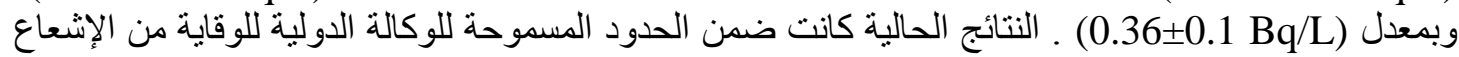

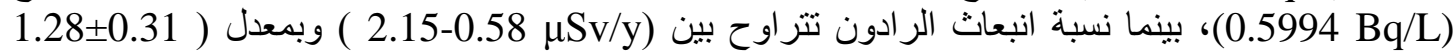

الكلمات المفتاحية: نركيز الرادون، تربة، نسبة انبعاث الر ادون، كاثف الاثر النووي (CR-39) ـ 